\title{
Robust FDI Determinants:" Bayesian Model Averaging In The Presence Of Selection Bias
}

\author{
Theo Eicher \\ University of Washington \\ Lindy Helfman \\ University of Washington \\ Alex Lenkoski \\ Heidelberg University
}

Version 2.0

$11 / 7 / 2011$

\begin{abstract}
The literature on Foreign Direct Investment (FDI) determinants is remarkably diverse in terms of competing theories and empirical results. We utilize Bayesian Model Averaging (BMA) to resolve the model uncertainty that surrounds the validity of the competing FDI theories. Since the structure of existing FDI data is well known to induce selection bias, we extend BMA theory to HeckitBMA in order to address model uncertainty in the presence of selection bias. We show that more than half of the previously suggested FDI determinants are not robust and highlight theories that do receive robust support from the data. Our selection approach allows us to identify the determinants of the margins of FDI (intensive and extensive), which are shown to differ profoundly. Our results suggest a new emphasis in FDI theories that explicitly identify the dynamics of the intensive and extensive FDI margins.
\end{abstract}

\footnotetext{
* We thank an anonymous referee, Christian Lorenczik, Monique Newiak, and Chris Papageorgiou for helpful suggestions. Assaf Razin and Hui Tong kindly shared their data. Lenkoski gratefully acknowledges support by the joint research project "Spatio/Temporal Graphical Models and Applications in Image Analysis" funded by the German Science Foundation (DFG), grant GRK 1653 as well as the MAThematics Centre Heidelberg (MATCH). Eicher thanks Max Soto Jimènez, the Instituto de Investigaciones en Ciencias Económicas, and the Department of Economics at the University of Costa Rica for their support and hospitality during the preparation of this paper.
} 


\section{Introduction}

Global FDI flows increased tenfold, or by about \$2 trillion, from 1990 to 2008 (UNCTAD, 2009), nevertheless a consensus on robust FDI determinants is still elusive. Although remarkably diverse FDI theories have motivated a range of potential FDI determinants, empirical FDI approaches commonly juxtapose only limited subsets of candidate regressors. ${ }^{1}$ In light of this model uncertainty, it comes as no surprise that FDI coefficient estimates are well known to be ambiguous and, at times, contradictory. The most comprehensive FDI survey to date (Blonigen, 2005) summarizes the FDI model uncertainty succinctly: "in the final analysis, the empirical literature on determinants of FDI is still young enough that most hypotheses are still up for grabs.”

Using Extreme Bound Analysis, Chakrabarti (2001) provided the first systematic evidence of the fragility of FDI determinants. ${ }^{2}$ The ad hoc Extreme Bound approach has since been superseded by statistical theory, which developed Bayesian Model Averaging (BMA) to account for model uncertainty as part of the estimation procedure (Raftery, 1995). The BMA approach is important since Berger and Sellke (1987) have shown that conventional sensitivity analyses overstate significance and confidence intervals in the absence of a full account of model uncertainty. When model uncertainty is not addressed comprehensively, it remains unclear whether a statistically significant FDI determinant remains relevant when alternative specifications/theories are considered. BMA methodology is thus tailor-made to examine the large set of candidate regressors that have been proposed as FDI determinants by alternative FDI theories.

An added complication in FDI empirics is that even the most comprehensive FDI datasets contain large sections of missing data. Selection bias may thus contaminate coefficient estimates, since it is unclear whether the nature of FDI forces the lion's share of investment to occur among OECD countries, or whether this observed FDI pattern is

\footnotetext{
${ }^{1}$ For example, Blonigen and Piger (2011) note that three key empirical FDI studies include no fewer than 22 different FDI determinants, but with little overlap. Baltagi et al. (2007) include a table that juxtaposes 4 alternative FDI theories that motivate 15 different FDI determinants.

${ }^{2}$ Leamer (1978) suggested Extreme Bound Analysis as an ad hoc sensitivity analysis in the presence of model uncertainty. EBA has been criticized for its lack of statistical foundations; it also restricted Chakrabarti (2001) to a limited number of models.
} 
an artifact of systematically missing observations. ${ }^{3}$ To address both model uncertainty and selection bias, we introduce HeckitBMA, which extends the statistical foundations of BMA to include Heckman’s (1979) selection bias procedure.

HeckitBMA reveals not only the determinants of the intensive and extensive margins of FDI ("the volume of investment flows" and "the decision to invest", respectively), it also permits us to estimate FDI determinants without having to constrain parameter estimates to be identical across both margins. There is no reason to suspect that the margins of FDI should feature identical determinants, nor that the same determinant has the identical impact for both margins. Our selection criterion is based on Razin, Rubinstein and Sadka (2004), who note that FDI involves fixed costs that give rise to two-part decisions: a marginal productivity condition that determines how much to invest, and a total profitability condition that indicates whether or not to invest abroad. Previous studies have confirmed the relevance of such FDI fixed costs. ${ }^{4}$

Our results show that the impact of model uncertainty on FDI estimates is substantial and that the Heckman selection methodology is necessary to obtain unbiased and consistent estimates. In the absence of explicit controls for model uncertainty, the conventional Heckit procedure suggests nearly three times as many FDI determinants as HeckitBMA at the extensive margin (32 vs 13) and a 50\% more regressors at the intensive margin. This is not surprising, since Heckit is not designed to consider models associated with alternative theories. Instead, HeckitBMA discovers much more parsimonious models of FDI that score better as measured by the Bayesian Information Criterion (BIC).

Robust FDI determinants that increase the intensive margin of FDI pertain not only to the host and source, but also to bilateral characteristics such as common history/language, as well as share PTA membership (APEC, LAIA) or a currency union (Dollar). Country characteristics that increase the volume of FDI flows include the host's lack of corruption, ethnic tension and bureaucratic red tape, as well as the source

\footnotetext{
${ }^{3}$ This FDI data issue has been well documented as early as Soto (2000). OECD data covers FDI activity among OECD countries comprehensively, but OECD/Non-OECD coverage is spotty and Non-OECD country-pairs are nonexistent.

${ }^{4}$ Caballero and Engel (1999), Razin, Rubenstein, and Sadka (2004), Razin and Sadka (2006).
} 
country's lack of internal conflict, corruption and ethnic tension. Economic characteristics that increase bilateral FDI flows include larger market size and lower taxes (in both source and host), as well as the host's productivity and GDP growth and the source country's level of development and investment profile. We highlight that these results are robust across subsamples, but that the OECD samples have a slightly different set of FDI determinants.

In stark contrast, the decision to invest is affected by markedly fewer determinants. Country characteristics that affect the extensive margin are common colonial history/borders, as well as the lack of religious tension in the host and lower corruption in source countries. Economic factors that increase the likelihood of FDI investment include host and source country market size, as well as the host's market potential and level of development. Greater source country productivity, taxation, or economic tensions decrease the likelihood that FDI is undertaken.

The importance of these FDI determinants is best appreciated once we relate the individual regressors back to specific FDI theories. We find only mixed support for horizontal or export platform FDI theories (Markusen, 1984). Trade agreements and currency unions do not encourage FDI across the board but only in specific instances (e.g., dollarization and APEC membership). Market potential exerts a decisive effect on FDI, but as in Blonigen et al. (2007), we find the effect runs counter to the theory prediction: a host's proximity to large markets results in less FDI - as large, proximate markets divert FDI from smaller potential hosts. Vertical FDI incentives (Helpman, 1984) are not strongly supported as we find that FDI is sensitive to higher levels of development or development differentials. Contrary to the knowledge-capital model (Markusen et al., 1996 and Markusen, 1997), we find no evidence that educational differences exert robust effects on the margins of FDI. HeckitBMA does confirm the Razin et al. (2007a) hypothesis that productivity is a crucial determinant of the decision to invest, together with corporate taxes in source and host countries. Bilateral tax treaties, in contrast, are shown to exert no impact on FDI, supporting the view that such treaties are created not only to facilitate investment, but also to restrict tax evasion and transfer pricing (the latter reduce FDI incentives). 
Closely related to our paper is the body of work of Razin and Sadka (2007b), who separate the decision to invest from the quantity of FDI flows. Their pioneering empirical work also consistently documents evidence for selection bias in FDI regressions. ${ }^{5}$ We expand their approach to include the large number of regressors that have been suggested by alternative FDI theories. Methodologically, our approach is related to Chakrabarti's (2001) Extreme Bound Analysis and to Blonigen and Piger (2011) who use Bayesian methods to analyze model uncertainty surrounding FDI stocks in a cross section. In contrast, we examine the dynamics of FDI flows from 1988-2000 and control for selection bias.

\section{Empirical Methodology}

Bergstrand and Egger (2007) provide theoretical foundations that motivate the use of gravity equations to analyze FDI patterns. The gravity equation has become the most popular approach in examining FDI determinants (see Barba Vanaretti and Venables, 2004), suggesting that FDI flows can be modeled according to

$$
Y_{i j t}=\alpha_{0}+\alpha_{t}+\beta_{1} \log G D P_{i t}+\beta_{2} \log G D P_{j t}+\beta_{3} \log D_{i j}+\beta_{4} X_{i j t}+\varepsilon_{i j t},
$$

where the log of bilateral FDI at time $t, Y_{i j t}$, depends positively on the market size of host, $j$, and source, $i$, countries, $G D P_{j t}$, and $G D P_{i t}$, as well as on their bilateral distance, $D_{i j}$. Typically a matrix of covariates, $X_{i j t}$, is included to represent alternative FDI theories. These regressors are motivated at length in Section 4 below. The inclusion of time fixed effects, $\alpha_{t}$, is standard to eliminate bias resulting from aggregate global shocks. Time fixed effects also mitigate possible spurious correlation that could be introduced, for example, by the use of the U.S. CPI to deflate FDI flows.

The canonical selection bias framework is given by the system of equations ${ }^{6}$

$$
\begin{aligned}
& Z=\theta^{\prime} W+\varepsilon \\
& Y=\beta^{\prime} X+\eta(\text { if } \mathrm{Z}>0)
\end{aligned}
$$

\footnotetext{
${ }^{5}$ FDI selection bias is also prominent in Davies and Kristjansdottir (2010), and Balsvik and Haller (2011).

${ }^{6}$ Whenever possible, we suppress subscripts to simplify notation.
} 
where $Y$ is the dependent variable, $X$ is a set of covariates, and $Z$ is an unobserved factor that dictates whether $Y$ is observed. $Z$ is determined by a set of variables $W$, where $X$ and $W$ may share several variables. The error term of (2) is jointly distributed

$$
\left(\begin{array}{l}
\eta \\
\varepsilon
\end{array}\right) \sim N\left(\left(\begin{array}{l}
0 \\
0
\end{array}\right),\left(\begin{array}{cc}
\sigma_{\varepsilon}^{2} & \sigma_{\eta \varepsilon} \\
\sigma_{\eta \varepsilon} & \sigma_{\varepsilon}^{2}
\end{array}\right)\right) \text {. }
$$

The classical selection bias arises when $\sigma_{\eta \varepsilon}^{2} \neq 0$, which causes the OLS estimates of $\beta$ that use only the observed values of $Y$ to be biased.

Heckman (1979) proposes a method to correct this bias. His Heckit model first performs a probit regression on $\mathrm{Z}$, which is equal to 1 if $Y$ is observed and 0 otherwise, using $W$ as covariates and yielding vector estimates, $\hat{\theta}$. Once $\hat{\theta}$ is found, $\tilde{Z}=\hat{\theta}^{\prime} W$ is formed to obtain the Inverse Mills Ratio, $\hat{\lambda}=\phi[\tilde{Z}] / \Phi[\tilde{Z}]$, which is the ratio of the probability density function over the cumulative distribution function of $\tilde{Z}$. In a second stage, those $Y$ that are observed are regressed on $X$ and the Inverse Mills Ratio, $\hat{\lambda}$, yielding the consistent vector estimates, $\hat{\beta}$. The Inverse Mills Ratio (sometimes called "selection hazard") is a function that is motivated by the properties of truncated normal distributions to control for selection bias. When the null hypothesis that the coefficient on the Inverse Mills Ratio is zero is rejected, selection bias is present and OLS estimates are downward biased.

HeckitBMA combines Heckit and BMA methodologies. Just like the Heckit methodology, HeckitBMA processes the data as a two stage estimator, but it also addresses model uncertainty in both stages. The first stage is an application of BMA for logistic regression based on Viallefont, Raftery and Richardson (2001) to form model averaged estimates of $Z$ and $\lambda$. Below we introduce the two HeckitBMA stages in detail.

As we introduce HeckitBMA notation, it is helpful to review BMA properties that are implied in stage 1 . Let $Z=\alpha+\sum_{i=1}^{p} \theta_{i} W_{i}+\varepsilon$, where $W_{1}, W_{2}, \ldots, W_{p}$ is a subset of $W_{1}, W_{2}, \ldots, W_{n}{ }^{7}$ The set of potential models is comprised of the individual models

\footnotetext{
${ }^{7}$ For a comprehensive BMA survey, see Raftery (1995) for detailed discussions and derivations.
} 
$\left\{M_{1}, \ldots, M_{S}\right\}$. BMA stipulates that the posterior distribution of $\theta$ given the data, $D$, is given by the weighted average of the predictive distribution under each model. The specific weights are derived from the models' corresponding posterior probabilities,

$$
\operatorname{pr}\left(\theta_{n} \mid D\right)=\sum_{n \in M_{s}}^{I} \operatorname{pr}\left(\theta_{n} \mid M_{s}, D\right) \pi_{s}
$$

where $\operatorname{pr}\left(\theta_{n} \mid M_{s}, D\right)$ is the predictive distribution given model $M_{s}$, and $\pi_{s}=\operatorname{pr}\left(M_{s} \mid D\right)$ is the model's prior probability. The posterior model probability for each first stage model is

$$
\begin{aligned}
& \pi_{s}=\operatorname{pr}\left(M_{s} \mid D\right)=\operatorname{pr}\left(D \mid M_{s}\right) \operatorname{pr}\left(M_{s}\right) \text {, where } \\
& \operatorname{pr}\left(D \mid M_{s}\right)=\int \operatorname{pr}\left(D \mid \theta_{s}, M_{s}\right) \operatorname{pr}\left(\theta_{s} \mid M_{s}\right) d \theta_{s}
\end{aligned}
$$

is the integrated likelihood of model $M_{s}$ with parameters $\theta_{s}$. The prior densities for parameters and models are $\operatorname{pr}\left(\theta_{s} \mid M_{s}\right)$ and $\operatorname{pr}\left(M_{s}\right)$, respectively. ${ }^{8}$

Posterior model probabilities are also the weights used to establish the posterior means and variances

$$
\begin{gathered}
\hat{\theta}^{\text {BMA }}=\sum_{s=1}^{S} \pi_{s} \hat{\theta}_{s} \\
\hat{\sigma}^{\text {BMA }}=\sum_{s=1}^{s}\left(\operatorname{Var}\left[\theta_{s} \mid D, M_{s}\right]+\left(\theta_{s}\right)^{2}\right) \pi_{s}-E\left[\theta_{s} \mid D\right]^{2}
\end{gathered}
$$

The posterior distribution for a parameter is a mixture of a regular posterior distribution and a point mass at zero, which represents the probability that the parameter equals zero. The sum of the posterior probabilities of the models that contain a variable yields its inclusion probability, which is taken as a measure of the importance of that variable. For instance, for variable $W_{k}$ we may write,

\footnotetext{
${ }^{8}$ We follow the literature with the standard assumption of uniform model priors (so that, ex ante, each model is presumed equally likely). Our parameter prior is the Unit Information Prior (see Raftery, 1995). This prior has been criticized as too conservative (e.g., returning too few effective regressors), but Eicher, Papageorgiou and Raftery (2011) show that in economic applications the prior density is sufficiently spread out to be reasonably flat over the region of the parameter space where the likelihood is substantial. Fernandez, Ley and Steel (2001) propose an alternative prior, which is also popular in economic applications. It is, however, significantly more conservative and can have lower predictive performance.
} 


$$
\mu^{B M A}\left(\theta_{W_{k}}\right)=\operatorname{pr}\left(\hat{\theta}_{W_{k}} \neq 0 \mid D\right)=\sum_{s \in M_{k}} \pi_{s}
$$

where $M_{k}$ is a collection of indices for which $s \in M_{k}$ implies model $M_{s}$ does not restrict the parameter $\theta_{k}$ to zero. The general rule developed by Jeffreys (1961) and refined by Kass and Raftery (1995) stipulates effect-thresholds for posterior probability. Posterior probabilities $<50 \%$ are seen as evidence against an effect, and the evidence for an effect is either weak, positive, strong, or decisive for posterior probabilities ranging from 5075\%, 75-95\%, 95-99\%, and > 99\%, respectively. In our analysis, we refer to a regressor as "effective," if its posterior inclusion probability exceeds $50 \%$.

\subsection{Selection Bias and HeckitBMA}

While BMA has previously been applied in the context of international economics, ${ }^{9}$ our specific FDI application requires an extension of the canonical BMA theory to account for selection bias. When the structure of the data suggests the potential of selection bias, the BMA framework in the previous section can be extended to a twostep Heckit model averaging procedure in which estimation is performed. HeckitBMA documents whether the absence of observed FDI flows is the result of randomly missing observations or due to endogenous FDI selection decisions that introduce bias to OLS coefficient estimates in previous FDI studies.

HeckitBMA is a nested BMA approach that establishes the posterior model probabilities in the first stage according to the BMA methodology, determining both $\pi_{s}$ and $\tilde{Z}_{s}$, as well as the first stage fitted values for each model $M_{s}$. The methodology then forms the model averaged fitted value according to ${ }^{10}$

$$
\tilde{Z}^{B M A}=\sum_{s=1}^{S} \pi_{s} \tilde{Z}_{s}
$$

\footnotetext{
${ }^{9}$ See e.g., Eicher, Henn, and Papageorgiou (2008) and Blonigen and Piger (2011). Other BMA applications in economics include investigations of growth determinants such as Fernandez, Ley and Steel (2001) and Eicher, Papageorgiou and Raftery (2011), Iterative BMA in Eicher, Papageorgiou and Roehn (2007) and 2SLSBMA in Eicher, Lenkoski, and Raftery (2009).

${ }^{10}$ An alternative Bayesian approach to sample selection models involves the imputation of the censored observations (see e.g. Chapter 14 of Koop et al.). On paper, such an approach is appealing, since the posterior distribution can be approximated through the seemingly straightforward application of a Gibbs sampler. However, in practice the requirement that such a large number of missing values be imputed at each step of the sampler may lead to considerable autocorrelation in the Markov Chain (see Omori 2007), thereby causing convergence to be extremely slow, if not practically impossible.
} 
and derives from this the Inverse Mills Ratio, $\hat{\lambda}^{B M A}=\phi\left[\tilde{Z}^{B M A}\right] / \Phi\left[\tilde{Z}^{B M A}\right]$.

The second-stage model selection procedure is follows the classical linear regression BMA, as outlined in Hoeting et al. (1997), with the model-averaged inverse mill's ratio added as an additional variable in each specification. In terms of the priors on the models/parameters we use the Unit Information Prior (UIP), which facilitates the BIC approximation, as outlined in Raftery (1995). Denoting by $L=\left\{L_{1}, \ldots, L_{N}\right\}$ the set of second stage models, HeckitBMA uses $\hat{\lambda}^{\text {BMA }}$ and the data, D, to derive the second stage posterior model probabilities, $v_{n}=\operatorname{pr}\left(L_{n} \mid D\right)$, and estimates, $\hat{\beta}_{n}$, for each model $L_{n} \in L .{ }^{11}$ The HeckitBMA posterior mean and variance are then given by

$$
\begin{gathered}
\hat{\beta}^{\text {HeckitBMA }}=\sum_{n=1}^{N} v_{n} \hat{\beta}_{n} \\
\hat{\sigma}^{\text {HeckitBMA }}=\sum_{n=1}^{N}\left(\operatorname{Var}\left[\beta_{n} \mid D, L_{n}, \hat{\lambda}^{B M A}\right]+\left(\beta_{n}\right)^{2}\right) v_{n}-E\left[\beta_{n} \mid D, \hat{\lambda}^{B M A}\right]^{2}
\end{gathered}
$$

Equation (10) shows that the HeckitBMA estimate is formed as the average of each estimate that results from using the combination of $\hat{\lambda}^{\text {BMA }}$ and model $L_{n}$ in the second stage, weighted by the second stage probabilities. As in traditional BMA, we can calculate the inclusion probabilities as

$$
\mu^{\text {HeckitBMA }}\left(\beta_{X_{k}}\right)=\operatorname{pr}\left(\hat{\beta}_{X_{k}} \neq 0 \mid D\right)=\sum_{n \in L_{k}} v_{j}
$$

The HeckitBMA inclusion probability carries the same interpretation as in the conventional BMA methodology. The only difference is that the inclusion probability is now based on estimates and model probabilities that account for selection bias. ${ }^{12}$

\footnotetext{
${ }^{11}$ Note this implies that the inverse Mills ratio, $\hat{\lambda}^{\text {BMA }}$, is not subject to model selection, hence we cannot use its inclusion probability as an indicator for the existence of selection bias. Instead the Mills ratio's Bayesian Credible Interval is used.

${ }^{12}$ To search the model space effectively, we used the Mode Oriented Stochastic Search (MOSS) algorithm developed by Lenkoski and Dobra (2011) and ran it from different starting points to ensure consistent results. The MOSS algorithm is a variant of the Shotgun Stochastic Search (SSS) algorithm (see Hans, et al., 2007) and has been shown to produce better or equal results as MC3 (Raftery et al, 1997) or Leaps and Bounds (Furnival and Wilson, 1974) while being able to handle many more candidate regressors. Our results would be unchanged had we used, for instance, SSS. MOSS essentially reproduces results in Eicher et al., 2011, which had been obtained using either MC3 or the Leaps and Bounds.
} 


\section{FDI Theories and Model Uncertainty}

This section outlines the model uncertainty surrounding FDI determinants, which requires a brief survey of existing FDI theories. Early FDI theory suggested two distinct motivations for FDI: horizontal FDI, which is undertaken to access markets when firms encounter trade restrictions, and vertical FDI, which leverages low factor prices in host countries to reduce production costs (see, e.g., Markusen, 1984 and Helpman, 1984). Markusen et al. (1996) and Markusen (1997) unified these two FDI motivations in the knowledge-capital model of FDI. Due to its complexity, closed-form solutions of the knowledge-capital model are elusive and simulated results highlight nonlinearities.

New trade theory provides for additional and more intricate FDI patterns. Ekholm, Forslid and Markusen (2007) and Bergstrand and Egger (2007) suggest export platform FDI is undertaken to serve not only the host country, but also to produce goods that are subsequently exported to neighboring countries. This strand of the literature highlights the importance of a comprehensive account of regional trade agreements in the empirical approach. Vertical interaction FDI is undertaken when subsidiaries in host countries ship intermediate goods back and forth for processing before exporting finished products back to the parent (see, e.g., Baltagi, Egger and Pfaffermayr, 2007).

These theories have been taken to the data with mixed success in a variety of econometric approaches. Carr, Markusen and Maskus (2001) provide evidence in favor of horizontal and vertical FDI that is consistent with the knowledge-capital model. Bergstrand and Egger (2007) introduce a third mobile factor (physical capital) to the knowledge-capital model to highlight the interaction between trade agreements and FDI flows. They find substantial evidence for effects of RTAs on FDI flows, which vanish, however, when transport and investment costs are included.

Yeaple (2003) utilizes affiliate sales to their parent companies to interact factor endowment differences with industry factor intensities. He reports positive evidence for both vertical and horizontal FDI motivations. Coughlin and Segev (2000) focus on export platform FDI by exploring possible regional/spatial FDI patterns to find evidence for export platform FDI and agglomeration externalities. Further support for export platform 
FDI is provided by Blonigen et al. (2007), who estimate negative FDI effects associated with neighboring-country FDI, using US/EU data.

Finally, Baltagi, Egger, and Pfaffermayr (2007) develop a general model of FDI in a multi-country world. It predicts how neighboring country characteristics (e.g., GDP, trade costs, endowments, etc.) affect FDI in a given host country, depending on the specific FDI motivation (horizontal, vertical, export-platform, etc.). They find mixed evidence and only weak support for export-platform and vertical interaction FDI.

\section{Existing Empirical Approaches and Candidate Regressors}

The above set of FDI theories and their associated empirical approaches motivate a substantial set of candidate regressors that identify FDI determinants. ${ }^{13}$ In this section we outline the set of regressors that have been associated with each of the above mentioned theories as well as the regressors that are commonly added to FDI gravity equations as additional controls (see Table 1 for a summary).

Aside from the typical gravity variables specified in (1), generic regressors such as Language, Border, and Colonial History are usually added to capture country-pair specific effects that might induce/obstruct FDI. In addition, the Real Exchange Rate is included in the gravity model as depreciations in the host country are thought to increase both the intensive and extensive margins of FDI (Goldberg and Klein, 1998). Depreciations reduce the amount of foreign currency needed to purchase assets abroad, and reduce the nominal return to the source in terms of foreign currency. Hence the often insignificant real exchange rate coefficient should not be surprising in large panel FDI studies.

Factor endowments are another key determinant of FDI. GDP Per Capita is commonly included to proxy for FDI that leverages differences in incomes, development, or capital abundance. As a measure of country income level, per capita GDP is expected

\footnotetext{
${ }^{13}$ Note that a number of these determinants, such as real per capita GDP, GDP growth rate, productivity, exchange rate, may well be suspected to be endogenous (see e.g, Russ, 2007 and Bergstrand and Egger, 2007) . Also trade and trade agreements may well be endogenous (see e.g, Blonigen 2010 or Aizenman and Noy (2004, 2005). Previous approaches to resolving endogeneity and model uncertainty include Tsangarides (2004), Chen, Mirestean, and Tsangarides (2009), Mirestean and Tsangarides (2009), as well as Moral-Benito (2009). We leave the thorny issue of developing a statistical theory of both endogeneity and selection bias to future research.
} 
to increase FDI flows for both source and host countries. As a measure of capital abundance, per capita GDP is predicted to generate positive FDI outflows for source countries and negative flows for host countries, since basic FDI models imply flows from capital-abundant to labor-abundant countries (Egger and Pfaffermayr, 2004). Education differences among country pairs are a proxy for vertical FDI motivations. According to the knowledge-capital model, greater educational disparities are expected to promote larger vertical FDI outflows.

Prospective growth, proxied by GDP Growth, signals higher returns, which attract FDI to a host and reduce outflows from a source country (see Rodrick, 1999 and Lim, 2001). Ekholm, Forslid and Markusen, (2007), Blonigen et al. (2007), and Baltagi, Egger and Pfaffermayr (2007) also include Market Potential (the size of proximate third country markets) to indicate each country's attraction as an export platform. Great market potential signals that the country should receive more export platform FDI as the host can serve relatively large markets in its relative proximity. However, the coefficient of this regressor has seldom been reported to be of the right sign, given large and important outliers such as Japan. A third economic factor that is seen to exert crucial influence on FDI returns is Country Productivity (Razin, Rubenstein, and Sadka 2004, and Razin, Sadka, and Tong, 2008). Razin, Sadka, and Tong (2008) develop a theory where productivity increases affect FDI setup costs such that an increase in host productivity reduces the likelihood of new FDI, but increases FDI outflows to existing subsidiaries.

Blonigen (2005) highlights how Corporate Tax Rates and Tax Treaties influence FDI flows while Razin and Sadka (2007b, Ch 10) point out the differential impact of source/host tax rates. Host taxes reduce FDI primarily at the intensive margin and source tax rates increase FDI outflow primarily at the extensive margin. Increases in source countries' corporate taxes induce multinationals to establish new affiliates abroad, but the quantity of production transferred abroad increases when host countries' tax rates decline. Although the number of bilateral tax treaties has increased from 100 to over 2,500 since 1960 (Egger et al., 2006), the empirical evidence regarding their effects is ambiguous (see Davies, 2004 for a survey). Studies often do not differentiate between the intensive and extensive margins; when the margins of FDI are considered, as in Blonigen and Davies (2004) results show strong positive effects of existing tax treaties on FDI, but 
negative effects of new tax treaties (see also Egger et al., 2006). When Di Giovanni (2005) examines only the extensive margin of FDI, positive effects of tax treaties are reported. $^{14}$

Financial risk also serves as a central determinant of FDI. Razin, Sadka, and Tong (2008) include crucial risk measures in their econometric analysis. Economic and Political Risk have also featured prominently in recent growth regressions; variables that proxy for such risks are included in regressions to capture factors that impact the return on investment. Carr, Markusen, and Maskus (2001) first included variables that relate to economic and political risk, such as the risk of expropriation. It is usually thought that less risk increases inflows to a host and reduces outflows from a source country.

We also include measures of regional trade agreements and currency unions. There is considerable evidence that currency unions affect FDI, although much of the research has focused on Europe only (see e.g., Petroulas, 2007 and Baldwin et al., 2008). Trade and FDI are well known to be closely related, and Bernard, Jensen, and Schott (2009) find that roughly 50 percent of U.S. trade is intra-firm trade between affiliates of the same MNC. Here the thorny issue is endogeneity; hence we focus on the effects of Regional Trade Agreements (RTAs), which have a clear but not necessarily direct impact on FDI via export platform and/or horizontal/vertical FDI incentives. ${ }^{15}$ The ambiguity arises as RTAs might increase FDI to an export platform within the RTA, and reduce it to all other members of the RTA. In addition, RTAs alter firms' tariff-jumping FDI incentives to amplify export platform FDI effects (Blonigen, 2002). To separate trade effects that arise within and between RTAs, Eicher, Henn, and Papageorgiou (2008) highlight the importance of controlling for all possible individual RTAs rather than including just one average catch-all RTA effect.

\footnotetext{
${ }^{14}$ The design of tax treaties may also contribute to the ambiguous findings. While treaties reduce withholding taxes and double taxation; Radaelli (1997) and Gravelle (1988) assert that reducing tax evasion is the primary goal of U.S. tax treaties via reduced transfer pricing and Hines (1996) shows that the way in which source countries eliminate double taxation can have different implications for FDI activity.

${ }^{15}$ The Asia-Pacific Economic Community (APEC), the Dollar Currency Unions (DOLLAR), the European Economic Area (EEA), the European Free Trade Area (EFTA), the EU, the Eurozone (Euro), the Latin American Integration Agreement (LAIA), and the North American Free Trade Agreement (NAFTA) have sufficient observations to be included.
} 
Given the diversity of theories, the common approach has been to focus on specific effects, such as tax treaties, or particular RTAs. Since we are proposing to juxtapose alternative theories, we seek to include representative regressors that encompass as many of the previous approaches as possible. The number of previous approaches is only superseded by the remarkable diversity of the associated results. Table 1 summarizes the diversity of positive and negative effects that have be obtained for the same regressors in FDI studies; it highlights not only model uncertainty, but also the fragility of the results when model uncertainty is not accounted for as part of the statistical methodology. If different approaches focus only on particular subsets of the FDI model space, it is no surprise that the associated results generate potentially different conclusions for the same regressor. The purpose of HeckitBMA is to resolve this model uncertainty, which requires this comprehensive set of regressors.

\section{Data}

Our dataset is based on Razin, Sadka, and Tong (2008), which includes data on productivity, GDP per capita, skill differences, common language, distance, population, and host and source country financial risk. ${ }^{16}$ Their FDI outflow data was obtained from the OECD International Direct Investment Database (OECD) and deflated by the U.S. CPI. We augment the Razin et al. (2008) dataset to allow tests of the alternative theories outlined above. The additional data collected includes additional controls for tax rates, tax treaties, trade agreements, currency unions, institutions, market potential, market size, and exchange rate agreements.

Average effective corporate tax rates are calculated using the definition and information in Altshuler et al. (1998), Blonigen and Davies (2004), and U.S. Treasury Corporate Tax Files. A list of bilateral tax treaties was obtained from Neumeyer and Spess (2005). Trade Agreements (multilateral and bilateral), as well as currency union indicators were obtained from Eicher and Henn (2011). Market potential is constructed according to the definition provided in Blonigen et al. (2007).

\footnotetext{
${ }^{16}$ Financial risk is an index of five components: foreign debt as a percentage of GDP, foreign debt service as a percentage of exports of goods and services, current account as a percentage of exports of goods and services, net international liquidity as months of import cover, and exchange rate stability.
} 
For institutional variables we include country risk proxies that are obtained from International Country Risk Guides (ICRG 1985-2000), which also provides the exact variable definitions. Information on economic risk covers the host and source country's Corruption, Bureaucratic Efficiency, and Investment Profile. ${ }^{17}$ Political risk is proxied by Democratic Accountability, Ethnic Tension, Internal/External Conflict, Government Stability, Political Violence, Rule of Law, Military Government Participation, Religious Tensions, and a Socio-Economic profile (which includes unemployment, consumer confidence, and poverty measures). ${ }^{18}$ Our unbalanced panel finally covers years 19882000 and includes 46 countries (21 non-OECD), 803 unique country pairs with 14863 total observations, of which 64 percent indicate zero FDI flows. There are small differences between the 55 regressors in our study compared to the 56 regressors in Blonigen and Piger's (2011) cross section. These differences relate to the differences in time dimensions in the studies. Sources and summary statistics are provided in Table 2 and the frequencies of FDI host/source flows are provided in Table 3.

\section{FDI Determinants and Model Uncertainty}

To establish a benchmark, we commence with a set of diagnostics comparing OLS to BMA results, abstracting from the issue of selection bias. Table 4 shows that the OLS regression suggests a surprisingly large number of 34 statistically significant FDI determinants. In contrast, BMA produces a much more parsimonious set of 23 regressors based on models that are associated with lower BICs than OLS. The BMA results also allow somewhat of a comparison to Blonigen and Piger (2011), who also examine model uncertainty and FDI determinants, but who do not address selection bias. Here a cautionary note is in order, however, since Blonigen and Piger examine FDI stocks in one cross section (2000) while we examine the dynamics of FDI flows in a panel of over a dozen years, which renders a comparison to be difficult.

Comparing our preliminary diagnostic BMA results, which do not account for sample selection bias, with the results obtained from the same empirical methodology employed by Blonigen and Piger (2011), we find similar effects for regressors related to

\footnotetext{
${ }^{17}$ Investment profile measures government attitude toward inward investment as determined by (i) risk to operations, (ii) taxation, (iii) repatriation, and (iv) labor costs.

${ }^{18}$ ICRG variables are coded such that higher values reflect less risk.
} 
gravity, and similarities/differences in host/source income levels (capital per capita, education difference, skill levels, real GDP, GDP differences). Those BMA results that take advantage of the time/dynamic dimension of FDI highlight the differential effects of (a) taxation and productivity, (b) regional trade agreements (APEC), currency unions (dollar), and (c) non-economic country characteristics (common heritage language/history, corruption, internal conflict, religious tensions).

\subsection{FDI Determinants, Model Uncertainty and Selection Bias}

Our central object of interest is, however, to control for selection bias and model uncertainty simultaneously, since a large fraction of the data is either randomly or systematically missing. ${ }^{19}$ Tables 4 and 5 report both Heckit and HeckitBMA results to contrast the impact of model uncertainty on the number and types of FDI determinants at the intensive (extensive) FDI margins. ${ }^{20}$ The Tables document the importance of model uncertainty in the analysis of FDI determinants: Heckit suggests no fewer than 35 (32) FDI determinants at the intensive (extensive) margins, which is dramatically higher than the 23 (13) regressors suggested by HeckitBMA.

The substantially greater number of regressors suggested by Heckit indicates the importance of model uncertainty in FDI regressions. Heckit simply reports statistical significance associated with various FDI theories without accounting for the uncertainty whether the true theory is being examined. Accounting for this model uncertainty HeckitBMA results in Table 5 suggest that alternative models, which are much more parsimonious, receive far greater support from the data. This is confirmed by the difference between the joint likelihoods of the Heckit and the best models in HeckitBMA. The likelihood-ratio test, which does not penalize for the included number of regressors, easily rejects the Heckit model in favor of HeckitBMA's model that received the greatest

\footnotetext{
19 Strictly speaking the absence of FDI flows between country pairs may be due to (a) the lack of incentives for flows (even if there were no fixed costs), (b) setup costs that do not allow flows to take place, and (c) measurement errors. An alternative approach would be to simply include all zeros and ignore the selection equation. To implement the approach we would have to follow Eichengreen and Irwin (1995) and add a " 1 " to all observations, so that the dependent variable becomes $\ln [$ flow +1$]$, since $\ln [0]$ is not defined. The approach has been discussed extensively in Frankel (1996) and Santos Silva and Tenreyro (2006) and rejected as it leads to inconsistent estimates whose biases depend on the approach and dataset. ${ }^{20}$ As in Razin, Rubenstein, and Sadka (2004) we include a negative FDI lag, to account for negative FDI flows (e.g., the liquidation of foreign subsidiaries).
} 
weight in the model averaging procedure. Similarly, the Bayesian Information Criterion (BIC), which is used to compare the performance of nested model specifications, clearly favors HeckitBMA. Hence it is no surprise that Heckit overestimates significance levels to generate an excessively large number of FDI determinants. HeckitBMA provides not only fewer, but also different FDI determinants. It supports additional FDI determinants at both the intensive and extensive margins that were not significant in the Heckit methodology. The investment profile of the source country matters in for HeckitBMA flows but not for Heckit, while the EFTA PTA, the hosts financial risk and military involvement in government are shown to affect selection for HeckitBMA but not Heckit. We discuss the detailed results for the global sample and for an OECD subsample below.

\subsection{Robust FDI Determinants in the Global Sample}

In this section we detail robust FDI determinants for the global sample. We first examine regressors that are associated with the decision to invest. This FDI margin is crucially important given the structure of the data where large segments of observations are either zero because FDI is not profitable, or because the data is systematically missing. Both Heckit and HeckitBMA show that the gravity approach is appropriate and that the Heckman selection methodology is necessary. All gravity regressors exhibit high inclusion probabilities and correct magnitudes at both margins of FDI. In addition, we find that the Inverse Mills Ratio indicates decisive (or highly significant) evidence of selection bias in the HeckitBMA (or Heckit) procedures as reported in Tables 4 and 5 . The exclusion restriction (Past_FDI_Dummy) suggested by Razin et al. (2008) is shown to exert a decisive effect on the decision to invest. ${ }^{21}$ It is thus clear that a full account of firms' decisions to invest in a selection (or participation) stage is critical to eliminating the omitted variables bias that contaminates parameter estimates in pure OLS approaches. ${ }^{22}$

\footnotetext{
${ }^{21}$ Razin et al. (2008) propose that FDI setup costs imply a profitability threshold so that past FDI relations can serve as an exclusion restriction.

${ }^{22}$ Greene (1981) shows that in the presence of selection bias, the OLS estimator is biased downward and the degree of the bias is related to the proportion of data censored. Since $64 \%$ of the data in the OECD FDI dataset is potentially censored the bias may be substantial. This may be one reason why Blonigen and Piger’s (2011) approach does not produce a substantial number of robust FDI determinants.
} 
To simplify the discussion of the effects in Table 5, we group effective FDI determinants into two categories, "economic" and "country characteristics," and consider extensive and intensive FDI determinants in sequence. For the extensive FDI margin, HeckitBMA suggests that country characteristics such as a common linguistic, military, religious and ethnic tensions in the host, as well as religious tensions in the source country affect the likelihood of FDI flows. Economic factors that exert a positive effect on the extensive margin of FDI include a host's level of development, lower taxes and financial risk, while higher taxes and financial risk increase the likelihood of FDI outflows from a source country. Here it is important to note the importance of the inclusion of trade agreements, since both APEC and EFTA imply a great likelihood that FDI will be undertaken between member countries.

Robust FDI determinants increase the intensive margin of FDI pertain not only to the host and source, but also to bilateral characteristics such as common history/language, as well as share PTA membership (APEC, LAIA) or a currency union (Dollar). Country characteristics that increase the volume of FDI flows include the host's lack of corruption, ethnic tension and bureaucratic red tape, as well as the source country's lack of internal conflict, corruption and ethnic tension. Economic characteristics that increase bilateral FDI flows include larger market size and lower taxes (in both source and host), as well as the host's productivity and GDP growth and the source country's level of development and investment profile. Interestingly, a host's market potential reduces FDI flows, which is in line with previous empirical results, but at odds with the prominent export platform approach to FDI.

The results are also insightful in terms of the absence of effects that are commonly reported in the literature. Neither tax treaties nor skill differences are shown to exert effects on FDI. These results confirm the findings of the previous literature that tax treaties may not only facilitate, but also impede FDI when treaties are also designed to reduce tax evasion and transfer pricing. Blonigen and Piger (2011) also do not find that skill differences drive knowledge-capital FDI motives. 


\subsection{Robust FDI Determinants Across OECD Countries}

Our previous results presuppose that a uniform set of FDI determinants governs FDI across all countries. There exists, however, ample evidence that subsamples of countries follow distinctly different development and FDI patterns. Masanjala and Papageorgiou (2008) highlight, for example, the differences in growth determinants for Africa, and Eicher et al. (2007) document differences in growth determinants for OECD countries, even after accounting for model uncertainty. In the context of FDI, Blonigen and Wang (2004) emphasize that data on FDI between countries are highly skewed, where the lion's share of activity is observed among developed countries while there is little or no activity for smaller developing nations. One approach to addressing the potential heterogeneity in FDI determinants is to separate developed and developing countries in empirical FDI studies. We proceed by running a simple diagnostic test (not reported here, but available from the authors) that adds a region dummy to our specification. While the core determinants results remain basically unchanged, the OECD dummy turns out to be an important determinant of FDI flows.

With this evidence for potential parameter in hand, we proceed to split the sample and examine the determinants of FDI flows for OECD country-pairs only (A non-OECD subsample is not possible since there are no reported flows for non-OECD country pairs). The results regarding the FDI determinants in the two subsamples are largely identical, although they differ in a few instances in rather expected fashion.

Among OECD country pairs, common language, EFTA, and military influence in governance are no longer relevant in the selection stage. This is not surprising, since there is hardly any variation in these variables across the OECD sample. Instead we find a number of additional selection criteria that determine the likelihood of FDI for OECD country pairs. Lower ethnic tension and higher levels of development increase the likelihood that one OECD source country invests in another. Again the market size of the host has a negative impact on the likelihood of FDI investment, which greater productivity in the host country lowers the probability of investment. The latter is a confirmation of the Razin et al. (2007) FDI fixed costs theory 
In terms of FDI flows among OECD countries, we find a similar pattern as in the selection equation, where a small set of regressors loose their effect while a sizable set of additional FDI determinants can be added. No longer relevant are the source's level of internal conflict, or the market size and investment profile of the host. At the same time, HeckitBMA discovers that OECD country pairs exhibit additional FDI flow determinants that did not exert effects in the global sample. Military interference in politics, government instability, and internal conflict increase FDI outflows from OECD source countries, while lower financial risk, less increased bureaucratic efficiency, and fewer ethnic tensions increase FDI flows to host countries. Notable are, however, also key parameters in the regression are not affected by the sample split. Neither the gravity equation parameters, nor regressors related to any of the FDI theories discussed above (excluding the export platform approach), nor the exclusion restriction experience sizable changes in the magnitudes of their effects.

\section{Conclusion}

FDI flows increased dramatically in the past 20 years. Over the same time period, the literature produced a dramatic proliferation of FDI theories as well as empirical FDI approaches. The uncertainty surrounding FDI theories and empirical approaches has created the notion that few FDI determinants are truly robust. Numerous empirical studies estimate only subsets of particular FDI theories to produce results that are often either inconclusive or outright contradictory. Statisticians refer to such diversity of theories and results as model uncertainty. When model uncertainty is not addressed comprehensively as part of the empirical strategy, traditional robustness analyses overstate significance levels and confidence intervals.

We extend the FDI literature in two dimensions. First, we construct a large dataset that represents a comprehensive set of FDI determinants that have been proposed by previous theories. Second, since large shares of FDI data are systematically missing from even the most detailed FDI dataset, we introduce HeckitBMA, which extends Bayesian Model Averaging to resolve the model uncertainty in the presence of selection bias. Our approach allows us to separate and estimate the determinants of two separate aspects of 
the FDI decision: a) the decision to invest abroad and b) how much to invest in a particular host country.

Our results show that the impact of model uncertainty on FDI estimates is substantial and that the Heckman selection methodology is necessary. Without controlling for model uncertainty, the conventional Heckit procedure suggests nearly twice as many FDI determinants as HeckitBMA at the extensive margin and 12 additional regressors (33\%) at the intensive margin. This is not surprising, since Heckit does not consider the models associated with alternative theories. Instead we find that HeckitBMA assigns the greatest weight to more parsimonious models that score dramatically better in terms of joint likelihoods or Bayesian Information Criteria (BIC). The determinants of the intensive and extensive margins of FDI are also shown to differ profoundly.

We find only mixed support for horizontal or export platform FDI theories (Markusen, 1984). Trade agreements and currency unions do not encourage FDI across the board, but only in specific instances (e.g., dollarization and APEC membership). Host country market potential is shown to exert a decisive effect on FDI flows, but the effect runs counter to the predictions of export platform FDI theory. As in Blonigen et al. (2007), we find that a host's proximity to large markets results in less FDI - as large, proximate markets divert FDI from a potential small host, perhaps to take advantage of scale economies. Vertical FDI theory (Helpman, 1984) is not strongly supported since FDI is sensitive to higher levels of development and, contrary to the knowledge-capital model, we find no evidence that educational differences exert robust effects on either the intensive or extensive margins. The one exception is that export platform FDI theories, as represented by our measure of market potential, no longer receives support from the data as an FDI flow or selection determinant. Given the market size of OECD countries we thus infer that export platform motivations for FDI are largely driven by differences in levels of development, which is not surprising since export platform FDI exploits not only the proximity to other large markets, but also the cost advantage of a particular producer. 


\section{References}

Aizenman, J., and I. Noy, 2004, "Endogenous financial and trade openness: Efficiency and political economy considerations," NBER Working Paper 10496.

Aizenman, J., and I. Noy, 2005, "FDI and trade," NBER Working Paper 11403.

Altshuler, R., H. Grubert, T.S. Newlon, 1998. "Has U.S. Investment Abroad Become More Sensitive to Tax Rates?” NBER Working Paper No. 6383.

Baldwin, R., Di Nino, V., Fontagné, L., De Santis, R., Taglioni, D., 2008. "Study on the Impact of the Euro on Trade and Foreign Direct Investment.” European Economy Economics Paper, 321.

Balsvik, R and S. A. Haller, (2011), "Foreign Firms and Host-Country Productivity: Does the Mode of Entry Matter?” Oxford Economic Papers, Vol 63, 1, pp 158-86

Baltagi, B. H., Egger, P., and Pfaffermayr, M. (2007) Estimating models of complex FDI: Are there third country effects?, Journal of Econometrics, 140, 260-281.

Bernard, A. E, J. B. Jensen and M. J. Schott. 2009. "Importers, Exporters, and Multinationals: A Portrait of Firms in the U.S. that Trade Goods" in Producer dynamics: New Evidence from Micro Data, 2009 T Dunne, JB Jensen and MJ Roberts Ed.s, University of Chicago Press

Berger, J. O., and Sellke, T. (1987), “Testing a Point Null Hypothesis: the Irreconcilability of $p$ Values and Evidence," Journal of the American Statistical Association, 82, 112-122.

Bergstrand, J. H., Egger, P., 2007. “A knowledge-and-physical-capital model of international trade flows, foreign direct investment, and multinational enterprises,” Journal of International Economics, 73, pp.278-308.

Blonigen, B. A. 2002. “Tariff-Jumping Antidumping Duties.” Journal of International Economics, Vol. 57, pp 31-50

Blonigen, B. A. and M. Wang, 2004, "Inappropriate Pooling of Wealthy and Poor Countries in Empirical FDI Studies," NBER Working Paper 10378.

Blonigen, B. A. and R. B. Davies, 2004. "The Effects of Bilateral Tax Treaties on U.S. FDI Activity,” International Tax and Public Finance, 11 (5), pp. 601-622.

Blonigen, B .A., 2005. “A Review Of The Empirical Literature On FDI Determinants,” Atlantic Economic Journal, 33, pp. 383-403.

Blonigen, B. A., R. B. Davies, G. Waddell and H. Naughton, 2007. "FDI in Space: Spatial Autoregressive Relationships in Foreign Direct Investment," European Economic Review, vol. 51(5), pages 1303-1325.

Blonigen, B. A. and J. Piger, 2011. "Determinants of Foreign Direct Investment” NBER 16704

Caballero, R. and E. Engel, 1999. "Explaining Investment Dynamics in US Manufacturing: A Generalized (S;s) Approach", Econometrica, July, 741-82.

Carr, D. L., J. R. Markusen, and Keith E. Maskus, 2001. "Estimating the KnowledgeCapital Model of the Multinational Enterprise," American Economic Review, vol. 91(3), pages 693-708, June.

Chakrabarti, A., 2001. “The Determinants of Foreign Direct Investment: Sensitivity Analyses of Cross-Country Regressions,” Kyklos, 54, pp. 89-114

Chen H., A. Mirestean, and C. Tsangarides, 2009, "Limited Information Bayesian Model Averaging for Dynamic Panels with Short Time Periods," IMF Working Paper $09 / 74$. 
Coughlin C. C. and E. Segev, 2000. "Foreign Direct Investment in China: A Spatial Econometric Study," The World Economy, vol. 23(1), 1-23.

Davies, R.B., 2004. "Tax Treaties and Foreign Direct Investment: Potential versus Performance,” International Tax and Public Finance, 11, pp. 775-802.

Davies R. B. and H. Kristjansdottir, 2010, "Fixed Costs, Foreign Direct Investment, and Gravity with Zeros," Review of International Economics, Blackwell Publishing, vol. 18(1), pages 47-62, 02.

Egger, P. and M. Pfaffermayr, 2004. "Foreign Direct Investment and European Integration in the 1990s," The World Economy, 27 (1), pp. 99-110.

Egger P. S., M. Larch, M. Pfaffermayr, H. Winner, 2006. "The impact of endogenous tax treaties on foreign direct investment: theory and evidence," Canadian Journal of Economics, vol. 39(3), pages 901-931, August.

Eicher, T. S. and C. Henn, 2011. "One Money, One Market: A Revised Benchmark," Review of International Economics, 19, 3, pp:19-435

Eicher, T. S., Papageorgiou, C., Raftery, A.E., 2011. ““”Default Priors and Predictive Performance in Bayesian Model Averaging, with Application to Growth Determinants” Journal of Applied Econometrics, 26, 1, pp: 30-55

Eicher, T. S., Papageorgiou, C., Roehn, O., 2007. "Unraveling the Fortunes of the Fortunate: An Iterative Bayesian Model Averaging (IBMA) Approach”, Journal of Macroeconomics, 2007:494-514

Eicher, T. S. C. Henn and C. Papageorgiou, 2008, "Trade Creation and Diversion Revisited: Accounting for Model Uncertainty and Natural Trading Partner Effects" Journal of Applied Econometrics, forthcoming

Eicher, T. S., A. Lenkoski and A.E. Raftery. (2009) "Bayesian Model Averaging and Endogeneity Under Model Uncertainty: An Application to Development Determinants" UW working paper 2009-19.

Ekholm, K., Forslid, R., and Markusen, J. R. (2007) Export-platform foreign direct investment, Journal of European Economic Association, 5, 776-795.

Fernández C., E. Ley and M. F. J. Steel. (2001). "Benchmark Priors for Bayesian Model 29 Averaging," Journal of Econometrics, 100, 381-427.

Furnival, G. M., \& Wilson, R. W. (1974). "Regression by leaps and bounds," Technometrics, 16, 4, pp:499-511.

Goldberg, L. and M. Klein, 1998, "Foreign Direct Investment, Trade and Real Exchange Rate Linkages in Developing Countries," in Managing Capital Flows and Exchange Rates: Perspectives from the Pacific Basin, Reuven Glick, ed, Cambridge University Press, pp73-100.

Gravelle, P. (1988), Tax treaties: Concepts, objectives and types, International Bureau of Fiscal Documentation, Bulletin 522, pp. 522-26.

Greene, W. 1981. "On the Asymptotic Bias of the Ordinary Least Squares Estimator of the Tobit Model.” Econometrica 49:505-513.

Helpman, E., 1984. "A simple theory of international trade with multinational corporations,” Journal of Political Economy, 92(3), pp.451-471.

Hines, J. R., 1996, “Altered States: Taxes and the Location of Foreign Direct Investment in America.” American Economic Review 86, 5: 1076-1094.

ICRG, various years, International Country Risk Guide Annual, PRS Group. 
Hans, C., Dobra, A, and West, M. (2007). "Shotgun stochastic search for 'large p' regression." Journal of the American Statistical Association 102, pp:507-516

Heckman, J., 1979. "Sample Selection Bias as a Specification Error," Econometrica, 47 (1), 153-161.

Jeffreys H. 1961. Theory of Probability. Oxford: Clarendon Press.

Kass, R. E. and A. E. Raftery, 1995. "Bayes Factors," Journal of the American Statistical Association, 90, pp. 377-95.

Koop, G., D.J. Poirier and J.L. Tobias. 2007. Bayesian Econometric Methods, Cambridge, Cambridge. University Press

Leamer, E. 1978. Specification Searches: Ad Hoc Inference with Non Experimental Data. New York: John Wiley and Sons.

Lenkoski, A. and Dobra, A. (2011). "Computational aspects related to Inference in Gaussian Graphical Models with the G-Wishart Prior.” Journal of Computational and Graphical Statistics, 20, pp:140-157.

Markusen, J. R. 1984. "Multinationals, Multi-plant Economies, and the Gains from Trade." Journal of International Economics, 16:3-4, pp. 205-26.

Markusen, J. R.; Venables, A. J.; Eby-Konan, D. and Zhang, K. H. 1996. “A Unified Treatment of Horizontal Direct Investment, Vertical Direct Investment, and the Pattern of Trade in Goods and Services.” NBER Working Paper No. 5696.

Markusen, J. R. 1997. "Trade versus Investment Liberalization." NBER Working Paper 6231.

Markusen, J.R. and K.E. Maskus. 2001. "Multinational Firms: Reconciling Theory and Evidence," in Topics in Empirical International Economics: A Festscrift in Honor of Robert E. Lipsey. Magnus Blomström and Linda S. Goldeberg eds. Chicago: University of Chicago Press, pp. 71-95.

Masanjala, W.H. and C. Papageorgiou (2008), Rough and Lonely Road to Prosperity: A Reexamination of the Sources of Growth in Africa Using Bayesian Model Averaging. Journal of Applied Econometrics 23, 671-682.

Mirestean A. and C. Tsangarides, 2009, "Growth Determinants Revisited," IMF Working Paper 09/268.

Moral-Benito, E., 2009, "Determinants of Economic Growth: A Bayesian Panel Data Approach," World Bank Policy Research Working Paper 4830.

Neumayer, E. and L. Spess, 2005. "Do Bilateral Investment Treaties Increase Foreign Direct Investment to Developing Countries?” World Development, 33(10), pp. 1567-1585.

Omori, Y, 2007. "Efficient Gibbs sampler for Bayesian analysis of a sample selection model," Statistics \& Probability Letters, 77, pp 1300-1311

Petroulas, P., 2007. "The effect of the euro on foreign direct investment," European Economic Review, 51(6), pp. 1468-1491.

Radaelli, C. M. (1997) The Politics of Corporate Taxation in the European Union, London, Routledge.

Raftery, A .E. (1995). "Bayesian Model Selection for Social Research," Sociological Methodology, 31, 25, 111-163.

Raftery, A.E., D. Madigan, and J. A. Hoeting (1997). "Bayesian Model Averaging for Linear Regression Models,” Journal of the American Statistical Association, 92, pp: 179-191. 
Razin, A., Y. Rubinstein, E. Sadka, 2004. "Fixed Costs and FDI: The Conflicting Effects of Productivity Shocks,” NBER Working Paper No. 10864.

Razin, A. and E. Sadka, 2006. "Vying For Foreign Direct Investment: A EU-Type Model of Tax Competition,” NBER Working Paper No. 11991.

Razin, A. and E. Sadka, 2007a. "Productivity and Taxes as Drivers of FDI," NBER Working Paper No. 13094.

Razin, A., E. Sadka, H. Tong, 2008. "Bilateral FDI Flows: Threshold Barriers and Productivity Shocks,” CESifo Economic Studies, 54 (3), pages 451-470.

Razin A. and E. Sadka, 2007b, Foreign Direct Investment: Analysis of Aggregate Flows Princeton University Press, Princeton, N.J.

Russ, K. N., 2007, "The endogeneity of the exchange rate as a determinant of FDI: A model of entry and multinational firms," Journal of International Economics, 71, 2 (April): pp344-372

Soto, M., 2000, "Capital Flows and Growth In Developing Countries Recent Empirical Evidence," OECD Workd Paper 160

Tsangarides, C.G., 2004, "A Bayesian Approach to Model Uncertainty," IMF Working Paper 04/68.

Viallefont, V., Raftery, A. E., Richardson S., 2001. "Variable selection and Bayesian model averaging in case-control studies," Statistics in Medicine, 20, pp. 32153230.

Yeaple, S. R., 2003. "The Role of Skill Endowments in the Structure of U.S. Outward Foreign Direct Investment," The Review of Economics and Statistics, 85(3), pp. 726-734. 
Table 1: Diversity of FDI Determinants and Their Estimated Effects

(Gravity Approaches Only)

\begin{tabular}{|c|c|c|c|c|c|}
\hline & \multirow{2}{*}{ Variable Name } & \multicolumn{3}{|c|}{ Estimated Effect In Past } & \multirow{2}{*}{ Variable Description } \\
\hline & & + & none & - & \\
\hline \multirow{3}{*}{ Gravity } & DISTANCEij & & 1 & 16 & natural log of bilateral distance \\
\hline & MRKT_SIZEi & 8 & 2 & & source natural log of real GDP \\
\hline & MRKT_SIZEi & 13 & 5 & 2 & host natural log of real GDP \\
\hline \multirow{3}{*}{$\begin{array}{c}\text { Geography / } \\
\text { History }\end{array}$} & BORDERij & 2 & 3 & & $=1$ if pair share a common border \\
\hline & COLONYij & 4 & 2 & & $=1$ if pair share colonial relationship \\
\hline & COM_LANGij & 10 & 3 & & $=1$ if pair share common language \\
\hline \multirow{3}{*}{$\begin{array}{c}\text { Factor } \\
\text { Endowment }\end{array}$} & DEVELOPMENTi & 3 & 4 & & source natural log of real GDP per capita \\
\hline & DEVELOPMENTj & 7 & 7 & & host natural log of real GDP per capita \\
\hline & EDU_DIFFij & 2 & 4 & 2 & source minus host education level \\
\hline \multirow{5}{*}{$\begin{array}{c}\text { Growth \& } \\
\text { Productivit } \\
\quad y\end{array}$} & GDP_GROWTHi & & & & source GDP growth rate \\
\hline & GDP_GROWTHj & 2 & 3 & & host GDP growth rate \\
\hline & MRKT_POTENTIALj & 1 & 1 & & sum of host's distance-weighted GDP to all other countries \\
\hline & PRODUCTIVITYj & 1 & 1 & & host productivity (real GDP per worker) \\
\hline & PRODUCTIVITYi & 1 & 1 & 1 & source productivity (real GDP per worker) \\
\hline \multirow{3}{*}{$\begin{array}{c}\text { Fiscal / } \\
\text { Monetary } \\
\text { Policy }\end{array}$} & TAXi & & 1 & & source corporate effective tax rate \\
\hline & TAXj & & 3 & 5 & host corporate effective tax rate \\
\hline & RERij & & 4 & 2 & real exchange rate (host/source currency) \\
\hline \multirow{11}{*}{$\begin{array}{l}\text { RTAs / CUs } \\
\text { / Investment }\end{array}$} & INVEST_TREATYij & 1 & 3 & & \\
\hline & RTAij & 0 & 0 & 0 & \\
\hline & Bi_RTAij & 1 & 3 & 1 & \\
\hline & NAFTAij & 1 & 3 & 1 & \\
\hline & EUij & 1 & 3 & & \\
\hline & EFTAij & 1 & 1 & & $=1$ if both countries are in a treaty \\
\hline & EEAij & & & & \\
\hline & LAIAij & & & & \\
\hline & APECij & 1 & 2 & & \\
\hline & EUROij & & & & \\
\hline & DOLLARij & & & & \\
\hline \multirow{6}{*}{$\begin{array}{c}\text { Economic } \\
\text { Risk }\end{array}$} & BUREAUj & 2 & & & host bureaucratic quality \\
\hline & BUREAUi & & & & source bureaucratic quality \\
\hline & CORRUPTj & 3 & 2 & & host corruption \\
\hline & CORRUPTi & & & & source corruption \\
\hline & FIN_RISKj & 2 & 2 & & host financial risk \\
\hline & FIN_RISKi & 1 & 2 & 2 & source financial risk \\
\hline \multirow{20}{*}{$\begin{array}{l}\text { Political } \\
\text { Risk }\end{array}$} & DEMOCRATICj & 1 & & & host democratic accountability \\
\hline & DEMOCRATICi & & & & source democratic accountability \\
\hline & ETHNIC_TENSIONj & & 1 & & host ethnic tentions \\
\hline & ETHNIC_TENSIONi & & & & source ethnic tentions \\
\hline & EXTERN_CONFLICTj & 1 & & & host external conflict \\
\hline & EXTERN_CONFLICTi & & & & source external conflict \\
\hline & GOV_STABILITYj & 2 & & & host government stability \\
\hline & GOV_STABILITYi & & & & source government stability \\
\hline & INTERN_CONFLICTj & & 1 & & host internal conflict \\
\hline & INTERN_CONFLICTi & & & & source internal conflict \\
\hline & INV_PROFILEj & 2 & & & host investment profile \\
\hline & INV_PROFILEi & & & & source investment profile \\
\hline & LAW__ORDERj & 2 & 1 & & host law and order \\
\hline & LAW_ORDERi & & & & source law and order \\
\hline & MILITARYj & & 1 & & host military in politics \\
\hline & MILITARYi & & & & source military in politics \\
\hline & RELIGIOUS_TENSION & & 1 & & host religion in politics \\
\hline & RELIGIOUS_TENSIONi & & & & source religion in politics \\
\hline & SOCIO_ECONj & & 1 & & host socioeconomic conditions \\
\hline & SOCIO_ECONi & & & & source socioeconomic conditions \\
\hline
\end{tabular}

Notes: Based on gravity FDI studies. Variables are listed as positive or negative if significant at the 5 percent level. 
Table 2: Descriptive Statistics

(Full Sample)

\begin{tabular}{|c|c|c|c|c|c|}
\hline & mean & sd & $\min$ & $\max$ & Source \\
\hline APECij & 0.09 & 0.28 & 0.00 & 1.00 & Eicher \& Henn (2011) \\
\hline Bi_RTAij & 0.01 & 0.12 & 0.00 & 1.00 & Eicher \& Henn (2011) \\
\hline BORDERij & 0.04 & 0.19 & 0.00 & 1.00 & Eicher \& Henn (2011) \\
\hline BUREAUi & 3.18 & 0.95 & 0.00 & 4.00 & International Country Risk Guide \\
\hline BUREAUj & 3.18 & 0.95 & 0.00 & 4.00 & International Country Risk Guide \\
\hline COLONYij & 0.03 & 0.18 & 0.00 & 1.00 & Eicher \& Henn (2011) \\
\hline COM_LANGij & 0.18 & 0.39 & 0.00 & 1.00 & RST(2008) \\
\hline CORRUPTi & 4.26 & 1.31 & 1.08 & 6.00 & International Country Risk Guide \\
\hline CORRUPTj & 4.25 & 1.33 & 1.08 & 6.00 & International Country Risk Guide \\
\hline DEMOCRATICi & 4.98 & 1.17 & 1.00 & 6.00 & International Country Risk Guide \\
\hline DEMOCRATICj & 4.96 & 1.21 & 1.00 & 6.00 & International Country Risk Guide \\
\hline DEVELOPMENTi & 5.35 & 1.38 & 1.71 & 9.10 & constructed from RST(2008) \\
\hline DEVELOPMENTj & 5.32 & 1.37 & 1.71 & 9.10 & constructed from RST(2008) \\
\hline DISTANCEij & 8.23 & 0.93 & 4.92 & 9.42 & $\mathrm{RST}(2008)$ \\
\hline DOLLARij & 0.00 & 0.04 & 0.00 & 1.00 & Eicher \& Henn (2011) \\
\hline EDU_DIFFij & 0.01 & 3.21 & -8.50 & 9.89 & RST(2008) \\
\hline EEAij & 0.08 & 0.27 & 0.00 & 1.00 & Eicher \& Henn (2011) \\
\hline EFTAij & 0.01 & 0.09 & 0.00 & 1.00 & Eicher \& Henn (2011) \\
\hline ETHNIC_TENSIONi & 4.84 & 1.28 & 1.00 & 6.00 & International Country Risk Guide \\
\hline ETHNIC_TENSIONj & 4.81 & 1.33 & 1.00 & 6.00 & International Country Risk Guide \\
\hline EUij & 0.10 & 0.30 & 0.00 & 1.00 & Eicher \& Henn (2011) \\
\hline EUROij & 0.01 & 0.10 & 0.00 & 1.00 & Eicher \& Henn (2011) \\
\hline EXTERN_CONFLICTi & 10.90 & 1.50 & 4.25 & 12.00 & International Country Risk Guide \\
\hline EXTERN_CONFLICTj & 10.86 & 1.59 & 4.25 & 12.00 & International Country Risk Guide \\
\hline FIN_RISKi & 39.95 & 7.24 & 18.00 & 50.00 & RST(2008) \\
\hline FIN_RISKj & 39.82 & 7.38 & 18.00 & 50.00 & RST(2008) \\
\hline GDP_GROWTHi & 0.04 & 0.04 & -0.13 & 0.13 & constructed from RST(2008) \\
\hline GDP_GROWTHj & 0.04 & 0.05 & -0.13 & 0.45 & constructed from RST(2008) \\
\hline GOV_STABILITYi & 7.61 & 1.99 & 1.00 & 11.00 & International Country Risk Guide \\
\hline GOV_STABILITYj & 7.57 & 2.04 & 1.00 & 11.00 & International Country Risk Guide \\
\hline INTERN_CONFLICTi & 10.04 & 2.24 & 3.00 & 12.00 & International Country Risk Guide \\
\hline INTERN_CONFLICTj & 10.02 & 2.27 & 3.00 & 12.00 & International Country Risk Guide \\
\hline INV_PROFILEi & 6.99 & 1.74 & 2.33 & 11.17 & International Country Risk Guide \\
\hline INV_PROFILEj & 6.98 & 1.75 & 2.42 & 11.17 & International Country Risk Guide \\
\hline INVEST_TREATYij & 0.11 & 0.31 & 0.00 & 1.00 & Neumayer and Spess (2005) \\
\hline LAIAij & 0.02 & 0.15 & 0.00 & 1.00 & Eicher \& Henn (2011) \\
\hline LAW_ORDERi & 4.73 & 1.41 & 1.00 & 6.00 & International Country Risk Guide \\
\hline LAW_ORDERj & 4.71 & 1.44 & 1.00 & 6.00 & International Country Risk Guide \\
\hline LOGFDI & 1.30 & 2.28 & -2.85 & 11.14 & RST(2008) \\
\hline MILITARYi & 4.90 & 1.44 & 1.00 & 6.00 & International Country Risk Guide \\
\hline MILITARYj & 4.86 & 1.52 & 0.00 & 6.00 & International Country Risk Guide \\
\hline MRKT_POTENTIALj & 0.51 & 0.21 & 0.22 & 1.64 & constructed see Blonigen et al., 2007) \\
\hline MRKT_SIZEi & 9.25 & 1.07 & 6.85 & 10.75 & RST(2008) \\
\hline MRKT_SIZEj & 9.24 & 1.10 & 6.06 & 10.75 & RST(2008) \\
\hline NAFTAij & 0.00 & 0.06 & 0.00 & 1.00 & Eicher \& Henn (2011) \\
\hline NEG_FDI_LAG & 0.05 & 0.22 & 0.00 & 1.00 & constructed from RST(2008)* \\
\hline PRODUCTIVITYi & 37.29 & 17.86 & 6.48 & 74.66 & RST(2008) \\
\hline PRODUCTIVITYj & 37.23 & 17.99 & 4.24 & 74.66 & RST(2008) \\
\hline RELIGIOUS_TENSIONi & 5.18 & 1.08 & 1.00 & 6.00 & International Country Risk Guide \\
\hline RELIGIOUS_TENSIONj & 5.14 & 1.16 & 1.00 & 6.00 & International Country Risk Guide \\
\hline RERij & 103.75 & 31.57 & 16.73 & 597.64 & USDA http://www.ers.usda.gov \\
\hline SOCIO_ECONi & 6.68 & 1.66 & 2.00 & 11.00 & International Country Risk Guide \\
\hline SOCIO_ECONj & 6.68 & 1.65 & 2.00 & 11.00 & International Country Risk Guide \\
\hline TAXi & 0.23 & 0.11 & 0.00 & 0.73 & 1980-92: Altshulter et al. (1998); 1994-02: \\
\hline $\mathbf{T A X} \mathbf{j}$ & 0.23 & 0.11 & 0.00 & 0.73 & IRS/SOI, World Tax Database \\
\hline
\end{tabular}

*This regressor is appropriate in the case where the desired FDI flows were negative

(as in the case where a foreign subsidiary is liquidated), but reported flows were zero. 
Table 3 Frequency of Host/Source Observations, By Country

\begin{tabular}{|c|c|c|c|c|}
\hline & \multicolumn{2}{|c|}{ FDI Hosts } & \multicolumn{2}{|c|}{ FDI Sources } \\
\hline & N obs & Obs $\neq 0$ & Nobs & Obs $\neq 0$ \\
\hline Argentina & 435 & 132 & 425 & 50 \\
\hline Australia & 390 & 214 & 386 & 155 \\
\hline Austria & 412 & 133 & 395 & 217 \\
\hline Belgium & 442 & 0 & 442 & 0 \\
\hline Brazil & 326 & 100 & 324 & 45 \\
\hline Canada & 405 & 165 & 402 & 161 \\
\hline Chile & 424 & 107 & 426 & 22 \\
\hline Colombia & 432 & 67 & 431 & 26 \\
\hline Costa Rica & 272 & 1 & 275 & 5 \\
\hline Denmark & 403 & 152 & 410 & 213 \\
\hline Egypt & 131 & 21 & 170 & 9 \\
\hline Finland & 406 & 127 & 379 & 231 \\
\hline France & 362 & 315 & 402 & 375 \\
\hline Greece & 425 & 123 & 415 & 44 \\
\hline Indonesia & 128 & 38 & 166 & 18 \\
\hline Ireland & 423 & 172 & 415 & 144 \\
\hline Israel & 436 & 77 & 422 & 79 \\
\hline Italy & 399 & 231 & 395 & 295 \\
\hline Japan & 397 & 180 & 438 & 355 \\
\hline Korea & 428 & 193 & 433 & 238 \\
\hline Malaysia & 354 & 94 & 362 & 53 \\
\hline Mexico & 309 & 193 & 357 & 34 \\
\hline Netherlands & 401 & 224 & 405 & 314 \\
\hline New Zealand & 372 & 124 & 387 & 104 \\
\hline Norway & 408 & 136 & 400 & 184 \\
\hline Pakistan & 169 & 28 & & \\
\hline Panama & 407 & 20 & 401 & 17 \\
\hline Philippines & 428 & 111 & 427 & 33 \\
\hline Poland & 31 & 20 & 28 & 12 \\
\hline Portugal & 405 & 205 & 416 & 160 \\
\hline Singapore & 288 & 87 & 289 & 66 \\
\hline South Africa & 166 & 52 & 193 & 30 \\
\hline Spain & 408 & 280 & 411 & 285 \\
\hline Sweden & 413 & 179 & 364 & 233 \\
\hline Switzerland & 398 & 157 & 388 & 279 \\
\hline Thailand & 426 & 121 & 426 & 34 \\
\hline Turkey & 397 & 125 & 433 & 64 \\
\hline United Kingdom & 409 & 257 & 397 & 341 \\
\hline United States & 373 & 291 & 392 & 356 \\
\hline Venezuela & 424 & 77 & 435 & 48 \\
\hline Total & 14462 & 5329 & 14462 & 5329 \\
\hline
\end{tabular}


Table 4: FDI Determinants, Model Uncertainty, and Model Selection

\begin{tabular}{|c|c|c|c|c|c|c|c|c|c|}
\hline \multirow[t]{2}{*}{$\begin{array}{l}\text { Sample } \\
\text { Estimation Method }\end{array}$} & \multicolumn{2}{|c|}{$\begin{array}{c}\text { FDI Flow } \\
\text { Global } \\
\text { OLS }\end{array}$} & \multicolumn{3}{|c|}{$\begin{array}{c}\text { FDI Flow } \\
\text { Global } \\
\text { BMA }\end{array}$} & \multicolumn{2}{|c|}{$\begin{array}{c}\text { FDI Flow } \\
\text { Global } \\
\text { Heckit }\end{array}$} & \multicolumn{2}{|c|}{$\begin{array}{c}\text { FDI Selection } \\
\text { Global } \\
\text { Heckit }\end{array}$} \\
\hline & mean & stdev & incl prob & post mean & post stedv & mean & stdev & mean & stdev \\
\hline APECij & $0.853^{* * *}$ & 0.089 & 1.00 & 0.823 & 0.084 & $0.815^{* * *}$ & 0.088 & $0.139 * *$ & 0.071 \\
\hline Bi_RTAij & $0.582 * * *$ & 0.198 & 0.03 & 0.009 & 0.062 & $0.508 * * *$ & 0.197 & $0.480 * * *$ & 0.135 \\
\hline BORDERij & 0.129 & 0.126 & 0.00 & 0.000 & 0.007 & $0.212^{*}$ & 0.126 & $-0.548 * * *$ & 0.111 \\
\hline BUREAUi & $0.239 * * *$ & 0.077 & 0.77 & 0.184 & 0.120 & $0.253 * * *$ & 0.076 & $-0.0712 *$ & 0.043 \\
\hline BUREAUj & 0.0360 & 0.060 & 0.03 & 0.003 & 0.019 & 0.0394 & 0.059 & -0.0502 & 0.039 \\
\hline COLONYij & $1.153^{* * *}$ & 0.111 & 1.00 & 1.135 & 0.110 & $1.086^{* * *}$ & 0.111 & $0.388 * * *$ & 0.104 \\
\hline COM_LANGij & $0.580 * * *$ & 0.073 & 1.00 & 0.663 & 0.071 & $0.547 * * *$ & 0.073 & $0.140 * * *$ & 0.053 \\
\hline CORRUPTi & $0.197 * * *$ & 0.039 & 1.00 & 0.218 & 0.031 & $0.189 * * *$ & 0.039 & $0.0660 * *$ & 0.027 \\
\hline CORRUPTj & $0.104 * * *$ & 0.037 & 0.98 & 0.115 & 0.035 & $0.103^{* * *}$ & 0.037 & 0.0375 & 0.027 \\
\hline DEMOCRATICi & 0.0535 & 0.040 & 0.01 & 0.001 & 0.007 & 0.0503 & 0.040 & $0.0451^{*}$ & 0.025 \\
\hline DEMOCRATICj & $0.0751^{* *}$ & 0.036 & 0.00 & 0.000 & 0.002 & $0.0755^{* *}$ & 0.036 & 0.0266 & 0.025 \\
\hline DEVELOPMENTi & $1.012 * * *$ & 0.028 & 1.00 & 1.054 & 0.026 & $0.960 * * *$ & 0.029 & $0.306 * * *$ & 0.021 \\
\hline DEVELOPMENTj & $0.862 * * *$ & 0.028 & 1.00 & 0.860 & 0.027 & $0.810^{* * *}$ & 0.029 & $0.302 * * *$ & 0.022 \\
\hline DISTANCEij & $-0.666 * * *$ & 0.036 & 1.00 & -0.712 & 0.026 & $-0.621 * * *$ & 0.037 & $-0.190 * * *$ & 0.029 \\
\hline DOLLARij & $4.361 * * *$ & 0.743 & 1.00 & 4.331 & 0.742 & $4.497 * * *$ & 0.735 & -0.260 & 0.365 \\
\hline EDU_DIFFij & 0.0179 & 0.012 & 0.01 & 0.000 & 0.001 & 0.0196 & 0.012 & -0.00515 & 0.009 \\
\hline EEAij & 0.0431 & 0.107 & 0.00 & 0.000 & 0.003 & 0.0129 & 0.107 & $0.229 * *$ & 0.096 \\
\hline EFTAij & -0.144 & 0.179 & 0.00 & 0.000 & 0.008 & -0.209 & 0.179 & 0.294 & 0.191 \\
\hline ETHNIC_TENSIONi & $0.151 * * *$ & 0.032 & 0.97 & 0.112 & 0.043 & $0.139 * * *$ & 0.032 & $0.0698 * * *$ & 0.019 \\
\hline ETHNIC_TENSIONj & 0.0184 & 0.028 & 0.00 & 0.000 & 0.001 & 0.0180 & 0.028 & $0.0355^{*}$ & 0.019 \\
\hline EUij & 0.0843 & 0.094 & 0.00 & 0.000 & 0.003 & 0.0951 & 0.094 & -0.0303 & 0.084 \\
\hline EUROij & 0.0957 & 0.180 & 0.00 & 0.000 & 0.010 & 0.0850 & 0.179 & -0.0322 & 0.178 \\
\hline EXTERN_CONFLICTi & 0.0354 & 0.027 & 0.00 & 0.000 & 0.001 & 0.0408 & 0.026 & -0.0287 & 0.018 \\
\hline EXTERN_CONFLICTj & -0.0287 & 0.025 & 0.01 & 0.000 & 0.005 & -0.0313 & 0.025 & 0.0160 & 0.017 \\
\hline FIN_RISKi & 0.0107 & 0.007 & 0.00 & 0.000 & 0.000 & 0.00864 & 0.007 & $0.0131 * * *$ & 0.005 \\
\hline FIN_RISKj & 0.00213 & 0.006 & 0.00 & 0.000 & 0.000 & 0.00185 & 0.006 & 0.00709 & 0.004 \\
\hline GDP_GROWTHi & 0.332 & 1.008 & 0.00 & -0.001 & 0.047 & 0.309 & 0.999 & -0.0330 & 0.618 \\
\hline GDP_GROWTHj & $3.172 * * *$ & 0.721 & 0.99 & 2.690 & 0.711 & $3.055 * * *$ & 0.716 & 0.379 & 0.454 \\
\hline GOV_STABILITYi & $0.0408^{*}$ & 0.025 & 0.01 & 0.000 & 0.002 & $0.0427 *$ & 0.025 & -0.0107 & 0.017 \\
\hline GOV_STABILITYj & $0.0551^{* *}$ & 0.022 & 0.09 & 0.003 & 0.011 & $0.0517 * *$ & 0.022 & 0.00582 & 0.016 \\
\hline INTERN_CONFLICTi & $-0.0999 * * *$ & 0.030 & 0.48 & -0.036 & 0.041 & $-0.0920 * * *$ & 0.030 & $-0.0350 *$ & 0.020 \\
\hline INTERN_CONFLICTj & $0.0569 * *$ & 0.026 & 0.82 & 0.065 & 0.037 & $0.0536 * *$ & 0.026 & -0.0168 & 0.018 \\
\hline INV_PROFILEi & 0.0162 & 0.027 & 1.00 & 0.095 & 0.016 & 0.0186 & 0.027 & -0.0235 & 0.019 \\
\hline INV_PROFILEj & $-0.0989 * * *$ & 0.026 & 0.00 & 0.000 & 0.001 & $-0.0903 * * *$ & 0.026 & $-0.0408 * *$ & 0.019 \\
\hline INVEST_TREATYij & $0.178^{* *}$ & 0.084 & 0.03 & 0.005 & 0.031 & $0.154^{*}$ & 0.083 & $0.125^{* *}$ & 0.055 \\
\hline LAIAij & $-1.012 * * *$ & 0.296 & 0.96 & -1.042 & 0.355 & $-1.032 * * *$ & 0.293 & $-0.240^{*}$ & 0.145 \\
\hline LAW_ORDERi & 0.0305 & 0.047 & 0.01 & 0.000 & 0.005 & 0.0316 & 0.047 & 0.0227 & 0.028 \\
\hline LAW_ORDERj & $0.0809 * *$ & 0.039 & 0.49 & 0.062 & 0.071 & $0.0763 * *$ & 0.039 & 0.0342 & 0.028 \\
\hline MILITARYi & -0.0412 & 0.049 & 0.00 & 0.000 & 0.003 & -0.0563 & 0.049 & -0.000431 & 0.028 \\
\hline MILITARYj & 0.00244 & 0.038 & 0.00 & 0.000 & 0.002 & 0.00321 & 0.038 & 0.0165 & 0.026 \\
\hline MRKT_POTENTIALj & $-0.479 * * *$ & 0.131 & 0.95 & -0.443 & 0.164 & $-0.494 * * *$ & 0.130 & $0.161^{*}$ & 0.093 \\
\hline MRKT_SIZEi & $0.425 * * *$ & 0.094 & 1.00 & 0.665 & 0.081 & $0.364 * * *$ & 0.093 & $0.334 * * *$ & 0.064 \\
\hline MRKT_SIZEj & $-1.143^{* * *}$ & 0.087 & 1.00 & -1.032 & 0.078 & $-1.097 * * *$ & 0.087 & $-0.144 * *$ & 0.062 \\
\hline NAFTAij & 0.0881 & 0.275 & 0.00 & 0.000 & 0.014 & 0.107 & 0.273 & 0.203 & 0.385 \\
\hline NEG_FDI_LAG & $-0.228 * * *$ & 0.071 & 0.59 & -0.126 & 0.119 & $-0.296 * * *$ & 0.072 & $0.829 * * *$ & 0.079 \\
\hline PRODUCTIVITYi & $0.00979 * *$ & 0.004 & 0.04 & 0.000 & 0.001 & $0.00955^{* *}$ & 0.004 & $-0.0106 * * *$ & 0.003 \\
\hline PRODUCTIVITYj & $0.0420 * * *$ & 0.004 & 1.00 & 0.040 & 0.004 & $0.0406 * * *$ & 0.004 & -0.00215 & 0.003 \\
\hline RELIGIOUS_TENSIONi & $0.0760 *$ & 0.040 & 0.01 & 0.000 & 0.004 & 0.0639 & 0.040 & $-0.0493 *$ & 0.026 \\
\hline RELIGIOUS_TENSIONj & $0.327 * * *$ & 0.036 & 1.00 & 0.304 & 0.034 & $0.306^{* * *}$ & 0.036 & $0.0551^{* *}$ & 0.026 \\
\hline RERij & $-0.00256 * *$ & 0.001 & 0.22 & -0.001 & 0.001 & $-0.00252 * *$ & 0.001 & 0.000376 & 0.001 \\
\hline SOCIO_ECONi & $0.0608^{* *}$ & 0.026 & 0.01 & 0.000 & 0.003 & $0.0578^{* *}$ & 0.026 & $0.0616 * * *$ & 0.017 \\
\hline SOCIO_ECONj & $0.0901 * * *$ & 0.023 & 0.15 & 0.007 & 0.018 & $0.0904 * * *$ & 0.023 & $0.0285^{*}$ & 0.017 \\
\hline TAXi & $-4.375^{* * *}$ & 0.288 & 1.00 & -4.601 & 0.274 & $-4.174 * * *$ & 0.288 & $-0.731 * * *$ & 0.199 \\
\hline TAXj & $-4.841 * * *$ & 0.278 & 1.00 & -4.787 & 0.267 & $-4.648 * * *$ & 0.277 & $-0.816^{* * *}$ & 0.203 \\
\hline PAST_FDI_DUM & & & & & & & & $2.191 * * *$ & 0.038 \\
\hline Inv_MILLS & & & & & & & & $-0.333^{* * *}$ & 0.054 \\
\hline $\begin{array}{l}\mathrm{BIC}^{1} \\
\mathrm{~N} \\
\end{array}$ & $\begin{array}{r}20826 \\
532 \\
\end{array}$ & & & $\begin{array}{c}20587.4 \\
5329 \\
\end{array}$ & & 53 & & & \\
\hline
\end{tabular}

${ }^{1}$ BMA statistic is based on best models in the selection stage. $* * * / * * * *$ indicate $1,5,10$ percent frequentist significance levels. Posterior means are conditional on inclusion. 
Table 5: Robust FDI Determinants

\begin{tabular}{|c|c|c|c|c|c|c|c|c|c|c|c|c|}
\hline \multirow[t]{2}{*}{$\begin{array}{l}\text { Sample } \\
\text { Estimation Method }\end{array}$} & \multicolumn{3}{|c|}{$\begin{array}{c}\text { FDI Flow } \\
\text { Global } \\
\text { HeckitBMA }\end{array}$} & \multicolumn{3}{|c|}{$\begin{array}{c}\text { FDI Selection } \\
\text { Global } \\
\text { HeckitBMA }\end{array}$} & \multicolumn{3}{|c|}{$\begin{array}{c}\text { FDI Flow } \\
\text { OECD } \\
\text { HeckitBMA }\end{array}$} & \multicolumn{3}{|c|}{$\begin{array}{c}\text { FDI Selection } \\
\text { OECD } \\
\text { HeckitBMA }\end{array}$} \\
\hline & $\begin{array}{l}\text { incl } \\
\text { prob }\end{array}$ & $\begin{array}{l}\text { post } \\
\text { mean }\end{array}$ & $\begin{array}{l}\text { post } \\
\text { stedv }\end{array}$ & $\begin{array}{l}\text { incl } \\
\text { prob }\end{array}$ & $\begin{array}{c}\text { post } \\
\text { mean }\end{array}$ & $\begin{array}{l}\text { post } \\
\text { stedv }\end{array}$ & $\begin{array}{l}\text { incl } \\
\text { prob }\end{array}$ & $\begin{array}{l}\text { post } \\
\text { mean }\end{array}$ & $\begin{array}{l}\text { post } \\
\text { stedv }\end{array}$ & $\begin{array}{l}\text { incl } \\
\text { prob }\end{array}$ & $\begin{array}{l}\text { post } \\
\text { mean }\end{array}$ & $\begin{array}{l}\text { post } \\
\text { stedv }\end{array}$ \\
\hline APECij & 1.00 & 0.761 & 0.133 & 0.72 & 0.159 & 0.115 & 1.00 & 0.985 & 0.204 & 1.00 & 1.330 & 0.423 \\
\hline COLONYij & 1.00 & 1.074 & 0.178 & 0.06 & 0.016 & 0.073 & 1.00 & 0.839 & 0.233 & 0.02 & -0.003 & 0.034 \\
\hline COM_LANGij & 1.00 & 0.642 & 0.113 & 1.00 & -0.505 & 0.106 & 1.00 & 0.508 & 0.141 & 0.01 & -0.001 & 0.010 \\
\hline CORRUPTi & 1.00 & 0.221 & 0.051 & 0.00 & 0.000 & 0.002 & 1.00 & 0.204 & 0.061 & 0.03 & 0.002 & 0.012 \\
\hline DEVELOPMENTi & 1.00 & 1.016 & 0.042 & 0.01 & 0.000 & 0.005 & 1.00 & 0.953 & 0.052 & 1.00 & 0.360 & 0.036 \\
\hline DEVELOPMENTj & 1.00 & 0.824 & 0.044 & 1.00 & 0.505 & 0.099 & 1.00 & 0.930 & 0.055 & 1.00 & 0.337 & 0.036 \\
\hline DISTANCEij & 1.00 & -0.682 & 0.043 & 0.12 & 0.015 & 0.044 & 1.00 & -0.744 & 0.056 & 0.99 & -0.121 & 0.032 \\
\hline DOLLARij & 1.00 & 4.434 & 1.194 & 0.05 & 0.003 & 0.012 & & & & & & \\
\hline MRKT_SIZEi & 1.00 & 0.543 & 0.124 & 0.01 & 0.000 & 0.004 & 0.01 & 0.001 & 0.022 & 0.01 & 0.000 & 0.013 \\
\hline MRKT_SIZEj & 1.00 & -1.036 & 0.124 & 0.02 & 0.001 & 0.005 & 1.00 & -2.047 & 0.255 & 0.82 & -0.439 & 0.234 \\
\hline PRODUCTIVITYj & 1.00 & 0.040 & 0.006 & 0.01 & 0.000 & 0.004 & 1.00 & 0.046 & 0.007 & 0.25 & -0.004 & 0.008 \\
\hline RELIGIOUS_TENSIONj & 1.00 & 0.284 & 0.054 & 1.00 & 0.249 & 0.019 & 1.00 & 0.294 & 0.091 & 0.66 & 0.123 & 0.098 \\
\hline TAXi & 1.00 & -4.462 & 0.446 & 1.00 & 0.244 & 0.026 & 1.00 & -3.612 & 0.531 & 1.00 & -2.147 & 0.329 \\
\hline $\mathbf{T A X j}$ & 1.00 & -4.636 & 0.435 & 1.00 & -0.201 & 0.025 & 1.00 & -4.821 & 0.545 & 1.00 & -2.189 & 0.336 \\
\hline GDP_GROWTHj & 1.00 & 3.073 & 1.071 & 0.00 & -0.001 & 0.030 & 1.00 & 7.472 & 2.230 & 0.01 & 0.001 & 0.123 \\
\hline NEG_FDI_LAG & 0.99 & -0.296 & 0.119 & 0.00 & 0.000 & 0.001 & 0.99 & -0.341 & 0.131 & 1.00 & 0.773 & 0.120 \\
\hline LAIAij & 0.98 & -1.113 & 0.490 & 0.01 & 0.000 & 0.008 & & & & & . & \\
\hline INTERN_CONFLICTj & 0.98 & 0.089 & 0.037 & 0.02 & 0.005 & 0.046 & 0.01 & 0.000 & 0.006 & 0.01 & 0.000 & 0.004 \\
\hline CORRUPTj & 0.97 & 0.121 & 0.053 & 0.02 & 0.001 & 0.004 & 1.00 & 0.249 & 0.070 & 0.09 & 0.009 & 0.033 \\
\hline INV_P & 0.96 & 0.076 & 0.035 & 0.10 & 0.004 & 0.014 & 0.04 & 0.002 & 0.013 & 0.02 & 0.000 & 0.005 \\
\hline MRKT_POTENTIALj & 0.93 & -0.433 & 0.235 & 0.00 & 0.000 & 0.004 & 0.98 & -0.650 & 0.271 & 0.01 & -0.001 & 0.022 \\
\hline ETHNIC_TENSIONi & 0.92 & 0.090 & 0.051 & 0.00 & 0.000 & 0.011 & 1.00 & 0.302 & 0.065 & 1.00 & 0.200 & 0.031 \\
\hline BUR & 0.79 & 0.188 & 0.140 & 0.01 & 0.000 & 0.001 & 1.00 & 1.624 & 0.162 & 0.01 & 0.000 & 0.011 \\
\hline LAW_ORDERj & 0.46 & 0.052 & 0.071 & 0.01 & 0.000 & 0.003 & 0.03 & 0.003 & 0.025 & 0.02 & 0.001 & 0.013 \\
\hline RERij & 0.19 & 0.000 & 0.001 & 0.08 & 0.001 & 0.003 & 0.01 & 0.000 & 0.000 & 0.02 & 0.000 & 0.000 \\
\hline INTER & 0.16 & -0.010 & 0.029 & 0.01 & 0.000 & 0.001 & 1.00 & -0.183 & 0.061 & 0.01 & 0.000 & 0.004 \\
\hline SOCIO_ECONj & 0.14 & 0.006 & 0.020 & 0.00 & 0.001 & 0.044 & 0.01 & 0.000 & 0.006 & 0.13 & 0.011 & 0.030 \\
\hline PRODUCTIVITYi & 0.08 & 0.001 & 0.003 & 0.01 & 0.003 & 0.051 & 0.18 & 0.002 & 0.005 & 1.00 & -0.019 & 0.004 \\
\hline Bi_RTAij & 0.06 & 0.023 & 0.115 & 0.00 & 0.000 & 0.001 & 0.19 & 0.122 & 0.297 & 0.10 & 0.045 & 0.152 \\
\hline SOCIO_ECONi & 0.06 & 0.004 & 0.017 & 0.01 & 0.000 & 0.001 & 0.01 & 0.000 & 0.006 & 0.40 & 0.035 & 0.048 \\
\hline GOV_STABILITYj & 0.05 & 0.002 & 0.011 & 0.00 & 0.000 & 0.001 & 0.01 & 0.000 & 0.006 & 0.01 & 0.000 & 0.003 \\
\hline BUREAUj & 0.03 & 0.003 & 0.023 & 0.01 & 0.000 & 0.003 & 1.00 & 0.878 & 0.150 & 0.01 & 0.001 & 0.015 \\
\hline DEMOCRATICi & 0.03 & 0.002 & 0.016 & 0.01 & 0.000 & 0.002 & 0.01 & 0.001 & 0.015 & 0.09 & 0.010 & 0.036 \\
\hline INVEST_TREATYij & 0.03 & 0.004 & 0.033 & 0.00 & 0.000 & 0.001 & 0.04 & 0.015 & 0.100 & 0.03 & 0.008 & 0.052 \\
\hline MILITARYi & 0.02 & -0.001 & 0.013 & 0.28 & 0.043 & 0.073 & 0.81 & -0.215 & 0.147 & 0.02 & -0.002 & 0.015 \\
\hline BORDERij & 0.02 & 0.003 & 0.032 & 0.01 & -0.002 & 0.024 & 0.04 & 0.007 & 0.050 & 0.02 & -0.004 & 0.032 \\
\hline INV_PROFILEj & 0.02 & -0.001 & 0.007 & 0.01 & 0.000 & 0.003 & 0.87 & -0.080 & 0.049 & 0.06 & -0.004 & 0.019 \\
\hline EDU_DIFFij & 0.02 & 0.000 & 0.003 & 0.02 & 0.001 & 0.006 & 0.01 & 0.000 & 0.002 & 0.01 & 0.000 & 0.001 \\
\hline EXTERN_CONFLICTj & 0.02 & 0.000 & 0.006 & 0.00 & 0.000 & 0.002 & 0.21 & -0.019 & 0.044 & 0.01 & 0.000 & 0.004 \\
\hline DEMOCRATICj & 0.02 & 0.001 & 0.009 & 0.01 & 0.000 & 0.002 & 0.02 & 0.002 & 0.019 & 0.01 & 0.000 & 0.005 \\
\hline GOV_STABILITYi & 0.02 & 0.000 & 0.006 & 0.01 & 0.000 & 0.009 & 0.57 & -0.050 & 0.055 & 0.01 & 0.000 & 0.004 \\
\hline FIN_RISKi & 0.01 & 0.000 & 0.001 & 1.00 & 0.409 & 0.054 & 0.01 & 0.000 & 0.002 & 0.86 & 0.026 & 0.014 \\
\hline LAW_ORDERi & 0.01 & 0.000 & 0.008 & 0.13 & -0.009 & 0.025 & 0.01 & 0.001 & 0.014 & 0.01 & 0.000 & 0.006 \\
\hline NAFTAij & 0.01 & 0.003 & 0.050 & 0.00 & 0.001 & 0.025 & & & & & & \\
\hline EFTAij & 0.01 & -0.001 & 0.028 & 1.00 & 0.836 & 0.078 & 0.01 & 0.002 & 0.033 & 0.02 & 0.004 & 0.040 \\
\hline RELIGIOUS_TENSIONi & 0.01 & 0.000 & 0.006 & 0.99 & -0.011 & 0.003 & 0.01 & 0.000 & 0.009 & 0.01 & 0.000 & 0.006 \\
\hline EEAij & 0.01 & 0.000 & 0.014 & 0.29 & -0.001 & 0.002 & 0.43 & -0.121 & 0.169 & 0.02 & 0.002 & 0.023 \\
\hline EUROij & 0.01 & 0.001 & 0.026 & 0.00 & 0.000 & 0.001 & 0.01 & -0.001 & 0.026 & 0.01 & -0.001 & 0.021 \\
\hline FIN_RISKj & 0.01 & 0.000 & 0.001 & 0.83 & 0.058 & 0.032 & 0.75 & 0.022 & 0.018 & 0.03 & 0.000 & 0.003 \\
\hline GDP_GROWTHi & 0.01 & 0.004 & 0.145 & 0.00 & 0.000 & 0.000 & 0.34 & 1.339 & 2.255 & 0.01 & 0.013 & 0.183 \\
\hline ETHNIC_TENSIONj & 0.01 & 0.000 & 0.004 & 0.68 & 0.030 & 0.023 & 1.00 & 0.210 & 0.059 & 1.00 & 0.205 & 0.038 \\
\hline EUij & 0.01 & 0.000 & 0.010 & 0.01 & 0.000 & 0.002 & 0.03 & -0.003 & 0.030 & 0.05 & -0.008 & 0.039 \\
\hline EXTERN_CONFLICTi & 0.01 & 0.000 & 0.003 & 0.09 & -0.040 & 0.140 & 0.11 & -0.009 & 0.033 & 0.01 & 0.000 & 0.004 \\
\hline MILITARYj & 0.01 & 0.000 & 0.005 & 0.65 & -0.401 & 0.331 & 0.02 & -0.001 & 0.015 & 0.01 & 0.000 & 0.006 \\
\hline PAST_FDI_DUM & & & & 1.00 & 2.241 & 0.038 & & & & 1.00 & 2.271 & 0.063 \\
\hline Inv_MILLS & & & & & $-0.33^{a}$ & 0.085 & & & & & $-0.51^{\mathrm{a}}$ & 0.127 \\
\hline $\begin{array}{l}\text { BIC }^{1} \\
N \\
\end{array}$ & & $\begin{array}{c}7581.85 \\
5329\end{array}$ & & & 14462 & & & $\begin{array}{c}4480.82 \\
3162\end{array}$ & & & 4841 & \\
\hline
\end{tabular}

${ }^{1}$ HeckitBMA statistics are based on best models in the selection and flow equations.

a The 95\% Credible Interval for the Inverse Mills Ratio does not contain zero. Posterior means are conditional on inclusion. 